\title{
Ethnobotanical review of food uses of Polygonatum (Convallariaceae) in China
}

\author{
Wujisguleng Wujisguleng ${ }^{1,2}$, Yujing Liu', Chunlin Long ${ }^{1 *}$ \\ ${ }^{1}$ College of Life and Environmental Sciences, Minzu University of China, Beijing 100081, China \\ ${ }_{2}^{2}$ Mongolian Medicine College, Inner Mongolia Medical University, Hohhot 010110, China
}

\section{Abstract}

According to our literature survey, fifteen species in the genus Polygonatum (Convallariaceae) have been used as food in China. Five main categories of use (drinks, snacks, vegetables, staple food and seasoning) were found. The plants from this genus are used mainly as vegetables. Rhizomes are the main parts used. The categories of use and diverse preparation methods have some similarities with those in other countries. Among all the recorded species, Polygonatum sibiricum and P. odoratum are the most commonly consumed species in China. Local people from different places have their own unique preparation methods and customs. However, the use of Polygonatum still remains at the level of family consumption, and the resources have not been fully used yet. We proposed ideas for further exploitation and conservation of edible Polygonatum species, and suggested further research, e.g. on the nutritional properties of all recorded edible species. It is believed that there is still plentiful traditional knowledge about food uses of Polygonatum to be documented in China.

Keywords: Polygonatum, food uses, ethnobotany, China

\section{Introduction}

China is the third largest country in the world. Its diverse climate and geography, varied terrain and range of soil types harbor an enormous diversity of plants, with 31142 species (of higher plants). At least 1156 species and 274 varieties and/or cultivars of food plants have been used by the inhabitants of China, who belong to 56 ethnic groups, including the dominant Han Chinese nationality [1]. Over thousands of years, they have accumulated very rich and precious traditional knowledge of using plants. That is why Prof. Richard I. Ford, a renowned ethnobotanist at University of Michigan at Ann Arbor, once said "the root of ethnobotany is in China". Since the 1980s, ethnobotanical studies have been carried out to document traditional knowledge of plant use in China, including wild food species [2-12]. It seems that using wild plants for food is more popular in southern China than in its northern part. Ethnic groups in some areas in southern China, like Yunnan Province, which harbors the richest diversity of plants in the country, consume more wild vegetables than cultivated ones. In some villages, which are far from the markets, wild vegetables are the local people's main sources of vegetable dishes [7].

\footnotetext{
* Corresponding author. Email: long@mail.kib.ac.cn
}

This is an Open Access digital version of the article distributed under the terms of the Creative Commons Attribution 3.0 License (creativecommons.org/licenses/by/3.0/), which permits redistribution, commercial and non-commercial, provided that the article is properly cited.
The plants in genus Polygonatum Mill. are perennial rhizomatous herbs belonging to the family Convallariaceae (also named Liliaceae). Up to June 2012, 63 species are accepted by the "World checklist of selected plant families" in the genus Polygoantum [13]. Plants in the genus are widely distributed in temperate regions of the northern hemisphere, mainly from the Himalayas to Japan, and especially in China and Japan, where approximately 40 different species of Polygonatum have been reported. They are also found in India, Korea, Afghanistan, Bhutan, Nepal, Pakistan and Russia. Polygonatum also grows in the temperate climate zones of northern and eastern America and Europe [14].

China is one of the richest countries in Polygonatum species, with 39 described species (61.9\% of the whole genus), and some studies suggest that China might be the distribution and differentiation center of the genus Polygonatum $[15,16]$. Among them, 20 species $(31.7 \%)$ are endemic. They are distributed throughout the country, and they can be found mainly in the northeast, Yunnan, Guizhou, Anhui, Guangxi, Hebei, Inner Mongolia, Henan, Shandong, Shanxi, Zhejiang, and Jiangxi provinces of China. Yunnan and Guizhou are the richest in Polygunatum species. The typical natural habitat of these plants is wet slope below $2000 \mathrm{~m}$ above sea level. Most of them grow in wet places and forests or bushes with thick and fertile soil [17].

Polygonatum species have a long history of traditional use, both as medicine and food, in China and other countries, like the northern and eastern United States, south-central Canada, India and Korea [18-20]. There are numerous ancient books describing medicinal and food uses of Polygonatum in China. It was recorded for the first time in the Mingyi Bielu (a pharmaceutical work, written at the end of Han Dynasty, AD 220), and ranked to the top grade of herbal medicine. Thereafter, 
all Chinese medicine scholars studied and documented it. "Got the essence of soil, be the first in tonics", a description of Polygonatum, was recorded in the famous Chinese medicinal book "Bencao gangmu" (i.e. "Compendium of materia medica", written by the famous medical expert Li Shizhen in Ming Dynasty, in 1590).

Polygonatum was recorded as a food item in the ancient medical works Shiliao Bencao and Jiuhuang Bencao as early as in the Tang Dynasty (AD 618-907). However, folk usage of Polygonatum in China should be much earlier than these ancient published works. Also in recent years, some ethnobotanical studies have documented the food uses of Polygonatum among the rural population (including various ethnic groups) [21-35].

This paper aims to review the traditional knowledge of $\mathrm{Po}$ lygonatum used as food in China. The objective is to gather and document information that will lead to a better understanding of the knowledge of traditional uses of Polygonatum in China.

\section{Results}

Fifteen species of Polygonatum are traditionally used as food in China through literature studies (Tab. 1). Five main categories of use (drink, snack, vegetable dish, staple food and seasoning) were found.

\section{Vegetables dishes ('cai')}

The largest category (14 species) is vegetable dishes ("cai"). In China "cai" is usually a plate of mainly one kind of vegetable eaten as a side-dish accompanying a meat dish and rice. Young leaves, stems and rhizomes are the main parts used, and are consumed raw or after frying, decocting, stewing, roasting or steaming. Different places have their own unique mode of preparation and consumptions.

One example is Simao, a tropical county in Yunnan, southwest China, with many minorities, e.g. Yi, Dai, and Lahu. The Dragon-boat festival is one of the important traditional holidays in China. In Simao, it is considered that this festival is the turning point of the wet and dry seasons in a year. Local herbal doctors believed that this time is when people are most vulnerable to disease, so people need to take some tonics to strength themselves and enhance immunity. They collected the rhizomes of $P$. cirrhifolium and $P$. kingianum, and braised them with chicken or pig's feet for use as tonics by people of all ages. The local people also considered that these dishes would strengthen the body, tranquilize the mind and increase appetite [6].

In Changbai Mountains, northeast China, because of the long and cold winter, the local people got used to eating steamed or roasted hot food. They usually use steamed or roasted rhizomes of $P$. sibiricum, $P$. odoratum, $P$. filipes, $P$. acuminatifolium, $P$. stenophyllum, $P$. humile, $P$. involucratum and $P$. inflatum as vegetables [23]. Also in northeast China, people like to eat some plants as salad, usually in the form of vegetables dressed with salty soybean paste. In northern China, fresh cultivated vegetables are not abundant in winter. During the summer or autumn, when plenty of green vegetables are harvested, the local people make some pickled vegetables (including wild vegetables), which can be stored for a long time. The sprouts of Polygonatum odoratum are salted for consumption in winter [31]. In some other places, the young leaves, stems, sprouts or rhizomes of $P$. odoratum are usually collected for use in fried dishes or salad, or for soup, after blanching [25].

\section{Drinks}

This group consists of three species used to prepare drinks, including wine or liquor and a substitute for tea. The rhizomes of $P$. sibiricum and $P$. nakaianum are soaked in rice wine for a month to make into herbal wine, which will make the drinkers' hair darker and brighter [35]. The rhizomes of $P$. odoratum are usually soaked with liquor and sugar for six months. Before use, the drink is strained with gauze. Drinking it frequently is supposed to eliminate fatigue, moisten skin, and make one beautiful. The rhizomes are also used as a substitute for tea. Some previous studies recorded that rhizomes of $P$. sibiricum were boiled with water for use as tea. It is believed that daily use of this tea will strengthen the body and is especially good for recovering from weakness [15].

\section{Snacks, staple foods, and seasonings}

Ten species are consumed as snacks. In the Inner Mongolian Autonomous Region, China, the rhizomes of $P$. sibiricum, $P$. odoratum, P. macropodium, were consumed as fresh "fruits" (snacks) by herdsmen. While the livestock were grazing on grassland, herdsmen could collect and eat edible plants any time they felt hungry or thirsty. Grassland areas have always been short on fruits. Because of their good taste, herdsmen usually took the rhizomes of Polygonatum as fresh "fruits" (snacks). They believed that people who eat the rhizomes of Polygonatum regularly will gain strength and live a long life [11]. In addition, the local Mongolians named P. sibiricum "imaan orhodai" and named P. odoratum "ebsen orhodai". Here "orhodai" means ginseng (Panax ginseng). It implied that the Mongolians have highly appreciated the values of these plants [34].

According to the nutritional study reported [35], the Polygonatum rhizomes are rich in starch (25.6-68.46\% of dry mass). The starch from P. sibiricum, $P$. odoratum, P. filipes, P. acuminatifolium, $P$. stencphyllum, $P$. humile, $P$. involucratum and $P$. inflalum has traditionally been used in China for a long time.

The local people in northeast of China steam or roast the Polygonatum rhizomes and eat them as a snack. The rhizomes are also fried with sugar and honey to make a kind of "candy" [22].

When used as staple food, the local people usually sun-dry the rhizomes of $P$. sibiricum, $P$. odoratum, and $P$. nakaianum, grind them into powder with a stone roller, then sift them to mix into flour to make cakes.

The local people also prepare the rhizomes of Polygonatum as seasonings to make some sweet dishes. The pulped rhizomes of P. sibiricum are boiled for 4 hours, then filtered, and $2 \%$ barley flour is added, to obtain a sugar solution. The sugar solution will be placed into a pot and boiled for 4 hours over a gentle heat. When the sugar solution is boiled into filamentous bright yellow droplets, the Polygonatum seasoning named sugar diluents ("tangxi”) was processed [36].

\section{Polygonatum uses in other countries}

In some other countries, some species in Polygonatum are believed to have medicinal properties [18], and have been used as a source of food too. For example, in India, Polygonatum cirrifolium and $P$. verticillatum are considered to be wild tasty leafy vegetables [19]. Polygonatum biflorum is distributed in the eastern United States and south-central Canada. Its starchy, edible rhizomes were formerly used by early Americans as a potato-like food or the starch was extracted and used to make bread, or mixed in with other foods such as soups. Young shoots can be added to salads, consumed raw or can be boiled 
Tab. 1 Species of Polygonatum traditionally used as food in China.

\begin{tabular}{|c|c|c|c|c|}
\hline Latin name & Used parts & Categories of use & Preparation methods & References \\
\hline \multirow[t]{2}{*}{ P. acuminatifolium Kom. } & Rhizome & Snack & Cooked (steamed or roasted) as snack & [23] \\
\hline & Sprout & Vegetable & $\begin{array}{l}\text { Raw (salad, pickled, dressed with sauce) or cooked (fried or } \\
\text { added to soups after blanching) }\end{array}$ & [31] \\
\hline \multirow[t]{2}{*}{ P. cirrhifolium (Wall.) Royle } & Young stem & Vegetable & Cooked & [7] \\
\hline & Tuber, rhizome & Vegetable & Raw (salad) or cooked as vegetable & {$[6,24,29,32]$} \\
\hline P. cyrtonema Hua & Rhizome, sprout & Vegetable & Cooked & {$[25,26,32]$} \\
\hline \multirow[t]{3}{*}{ P. filipes Merr. } & Rhizome & Vegetable, snack & Cooked as vegetable & [25] \\
\hline & & & Cooked (steamed or roasted) as snack & \\
\hline & Sprout & Vegetable & Cooked as vegetable & [25] \\
\hline \multirow[t]{2}{*}{ P. humile Fisch. ex Maxim. } & Rhizome & Vegetable, snack & $\begin{array}{l}\text { Raw (salad, pickled, dressed with sauce) or cooked (fried, } \\
\text { steamed, roasted or added to soups) as vegetable } \\
\text { Cooked (steamed or roasted) as snack }\end{array}$ & {$[23,28]$} \\
\hline & Sprout & Vegetable & $\begin{array}{l}\text { Raw (salad, pickled, dressed with sauce) or cooked (fried or } \\
\text { added to soups after blanching) }\end{array}$ & {$[28,31]$} \\
\hline \multirow[t]{2}{*}{ P. inflatum Kom. } & Rhizome & Snack & Cooked (steamed or roasted) as snack & [23] \\
\hline & Sprout & Vegetable & $\begin{array}{l}\text { Raw (salad, pickled, dressed with sauce) or cooked (fried or } \\
\text { added to soups after blanching) }\end{array}$ & [31] \\
\hline \multirow{3}{*}{$\begin{array}{l}\text { P. involucratum (Franch. et } \\
\text { Sav.) Maxim. }\end{array}$} & Rhizome & Vegetable, snack & Cooked as vegetable & {$[23,30]$} \\
\hline & & & Cooked (steamed or roasted) as snack & \\
\hline & Sprout & Vegetable & $\begin{array}{l}\text { Raw (salad, pickled, dressed with sauce) or cooked (fried or } \\
\text { added to soups after blanching) }\end{array}$ & {$[28,31]$} \\
\hline \multirow{3}{*}{$\begin{array}{l}\text { P. kingianum Coll. et Hemsl. } \\
\text { P. macropodium Turcz. }\end{array}$} & Tuber, rhizome & Vegetable & Raw or cooked (fried or stewed) & {$[6,7]$} \\
\hline & Rhizome & Vegetable, snack & $\begin{array}{l}\text { Cooked as vegetable } \\
\text { Raw as snack (fruit) }\end{array}$ & {$[12,23,28,34]$} \\
\hline & Sprout & Vegetable & $\begin{array}{l}\text { Raw (salad, pickled, dressed with sauce) or cooked (fried or } \\
\text { added to soups after blanching) }\end{array}$ & {$[28,31,32]$} \\
\hline \multicolumn{4}{|l|}{ P. Y. Li } & [57] \\
\hline P. nakaianum Ishidoga & Rhizome & Drink, staple food & $\begin{array}{l}\text { Raw as drink (wine) } \\
\text { Cooked as staple food (make into powder and mixed with } \\
\text { flour) }\end{array}$ & [35] \\
\hline \multirow[t]{3}{*}{ P. odoratum (Mill.) Druce } & $\begin{array}{l}\text { Young stem and } \\
\text { leave }\end{array}$ & Vegetable & Cooked (fried dish or added to soups after blanching) & {$[21,27-29]$} \\
\hline & sprout & Vegetable & $\begin{array}{l}\text { Raw (salad, pickled, dressed with sauce) or cooked (fried or } \\
\text { added to soups after blanching) }\end{array}$ & {$[28,31]$} \\
\hline & Rhizome & $\begin{array}{l}\text { Vegetable, drink, } \\
\text { snack, stale food }\end{array}$ & $\begin{array}{l}\text { Raw or cooked (steamed or roasted) as snack } \\
\text { Raw (wine) or cooked (boiled) as drink (substitute for tea) } \\
\text { Cooked (steamed) as vegetable } \\
\text { Make into powder and mixed with flour as staple food } \\
\text { Roasted on embers as famine food in some areas }\end{array}$ & $\begin{array}{l}{[11,23,27,28} \\
31,33-35,57]\end{array}$ \\
\hline \multirow[t]{2}{*}{ P. sibiricum Delar. ex Red. } & Sprout & Vegetable & Cooked (fried dish or added to soups after blanching) & {$[27,28,30]$} \\
\hline & Rhizome & $\begin{array}{l}\text { Vegetable, snack, } \\
\text { drink, staple food, } \\
\text { seasoning }\end{array}$ & $\begin{array}{l}\text { Raw (fruit) or cooked (steamed or roasted) as snack } \\
\text { Raw (pickled) or cooked (steamed, roasted, fried) as vegetable } \\
\text { Raw as drink (wine/liquor) } \\
\text { Boiled as substitute for tea } \\
\text { Make into powder and mixed with flour as staple food. } \\
\text { Cooked to make seasonings }\end{array}$ & $\begin{array}{l}{[11,21-23} \\
27,28,31-35]\end{array}$ \\
\hline P. stenophyllum Maxim. & Rhizome & Snack & Cooked (steamed or roasted) as snack & [23] \\
\hline P. verticillatum (L.) All. & Rhizome, sprout & Vegetable & Cooked & {$[24,28,29,32]$} \\
\hline
\end{tabular}

and served like asparagus [20]. Some species, in particular $P$. sibiricum, are used as a herbal tea called dungulle in Korea [13].

\section{Medicinal effect}

According to "China Pharmacopoeia" (2010), Rhizoma polygonati, prepared from the dried rhizomes of Polygonatum sibiricum, P. kingianum and P. cyrtonema, and processed $P$. odoratum products are the most commonly used medicines in Traditional Chinese Medicine (TCM). TCM considered that the former contains the properties of reinforcing "qi", nourishing "yin" and moistening the lungs, strengthening kidney and spleen, while the processed $P$. odoratum products have the properties of moistening heart and lungs, nourishing the stomach and enhancing bone marrow [37]. 
Different pharmacologically active groups of compounds have been isolated phytochemically, such as polysaccharides, saponins, phytohormones, glycosides, flavonoids and alkaloids. Pharmacological research has demonstrated that Polygonatum species produce effects, showing antihyperglycemic potential, anticancer, analgesic, antipyretic diuretic, antimalarial, antioxidant, antimicrobial, phytotoxic etc. [14]. Polysaccharides are the major bioactive compounds in these plants [38-41]. Phytochemical and pharmacological research on several species including $P$. odoratum, $P$. verticillatum, $P$. cyrtonema, $P$. kingianum have been reported. The research results have shown biological activities and possessed potentially medical applications [42-50]. In fact, based on our literature studies, we see that all the species recorded as used for food, also have medicinal effects. The local people in China believe that to take Polygonatum food enhances immunity and longevity, which are in full accord with the results of modern scientific research.

\section{Discussion and conclusions}

China is the richest country in Polygonatum resources, with 39 species (61.9\%). The local inhabitants of China have developed a rich traditional knowledge about the food use of this genus. Based on our literature survey, we have found 15 species used for food, out of which $P$. macropodium, $P$. cytonema, $P$. filipes are endemic to China. There are 5 main categories of use in China, including wild vegetables, drinks, snacks, staple food and seasonings. All the species in the genus have been used for vegetable dishes, 10 species for snacks, 3 species for making drinks, 3 species as staple food and 1 species for seasonings. Some species can be classified into more than one category. For example, the rhizomes of $P$. sibiricum have traditionally been used as elements of vegetable dishes, drinks, snacks, and as a staple food.

Preparation methods are also diverse. Some of the species are eaten as salad, directly or after simple processing. Some of them can only be eaten after being well-cooked or processed. The cooking methods include frying, decocting, stewing, roasting and steaming.

There are some interrelations between the used parts and categories of use. Young leaves, stems and rhizomes are mainly used in vegetable dishes. Rhizomes are used to make drinks, snacks and seasonings. Therefore the rhizomes are the most commonly used parts. Some ancient publications recorded that the roots, leaves, flowers and fruits of $P$. sibiricum were edible. Nowadays, however, there are no records about the use of flowers or fruits of this species as food [51]. Meanwhile, some literature sources report that the fruits of Polygonatum biflorum (not distributed in China), contain anthraquinone, which is poisonous, but with a low toxicity, mostly causing vomiting and diarrhea [52]. Thus the fruits of this species are not edible. Based on this information we should be aware of the toxicity of Polygonatum fruits. It is possible that the toxicity of a Polygoantum species varies depending on the place where it grows or which species, subspecies or variety is taken into account. Therefore further research on the chemistry of Polygonatum fruits is necessary to determine whether the fruits of Chinese Polygonatum species are edible or poisonous. Some nutritional studies on $P$. sibiricum seeds have been done recently, and showed that the contents of methionine, lysine and isoleucine are higher than those of wheat or corn, and suggested that the seeds of $P$. sibiricum could be eaten [53].

Local Chinese people from all over the country have used Polygonatum as food sources. The different places have their own distinctive features. They believe that it would enhance immunity and longevity to take Polygonatum as food, which is in full accord with the results of modern scientific research. However, the usages of Polygonatum are still at the family level of consumption. Although China is rich in wild Polygonatum resources, they have not been fully used and exploited yet. To explore and develop new resources, the traditional preparation methods of Polygonatum can provide information. Considering that the plants from this genus have both nutritional and medicinal value, they can be classified into the health food category and are worth developing into more widely used functional foods by combining modern food processing technology and traditional preparation methods. The following points should be taken into account:

(i) The wild species of Polygonatum are usually pollution free, so they are attractive to food processing industries.

(ii) As the plants have medicinal functions, the rhizomes of Polygonatum can be developed into functional foods such as "Polygonatum paste", "Polygonatum porridge", "Polygonatum powder" [54]. These products have already appeared on the market, but are not very commonly used.

(iii) The rhizomes are the main parts used for the development of food products. The rhizomes are soft and contain starch, other carbohydrates, carotene, vitamins and low coarse cellulose. They are suitable for making various drinks, such as wine, tea substitutes or different flavored drinks. They can be processed into snacks, such as dried, canned, or puffed foods. The fruits of $P$. sibiricun can be exploited as a vitamin B1 source [15]. In addition, other parts, such as seeds, are worth using, but further investigation into the nutritional properties of all useful parts is necessary.

(iv) The most popular consumed species of Polygonatum in China were P. sibiricum and P. odoratum (Tab. 1). However, there are still some other species, which are little known and processed. For example, $P$ c cyrtonema, which is rarely used for food by local people, has high nutritional quality, unique medicinal functions and plentiful wild resources [55]. P. filipes, which has a wide distribution in 8 provinces in China, i.e. Anhui, Fujian, Guangdong, Guangxi, Hunan, Jiangsu, Jiangxi and Zhejiang, was only used by the local people in Qiandaohu, Zhejiang Province. The Polygonatum plants in Anhui Province present another example. Anhui Province, located in eastern China, is one of the major production areas of Polygonatum in China, with 11 species of Polygonatum and the production of 20-100 tons every year [54]. However, the local people paid more attention to the medicinal value than the edible value so that a few species were collected and used for food. Further study and exploitation could be carried out regarding these species for product development.

(v) Most of the Polygonatum species are not protected. The local people mainly consume wild Polygonatum species for food, and the rhizomes are the main parts used. In addition, most of the Polygonatum plants used as medicines sold on the markets are also from wild specimens. All the above-mentioned factors have greatly damaged the local plant resources. There are some species, such as $P$. macropodium, $P$. kingianum, $P$. verticillatum, $P$. cirrhifolium, which have been frequently used both for food and medicine in some places. However, because of the increasing demand, their resources have shrunk. Given this situation, it is necessary to select the species which have the largest use potential for cultivation, or to conserve resources in situ to reduce threats to the rare species and their habitats. 
In the past, the Chinese used wild plants for food in famine times when main crops and cultivated vegetables were not available. Nowadays, however, with the intensive development of agricultural and marketing techniques, it is easy to find various cultivated fruits and vegetables and other food in markets throughout the year. Therefore, the younger generation has little awareness of using wild food plants, and the traditional knowledge of using plants for food survives only in the memory of the elders. As a result, it is eroding due to changing social values and a lack of participation of the younger generation in collection and processing of wild plants [56]. However, we believe that there is still plentiful traditional knowledge of food usage of Polygonatum to be documented in China, which can provide important scientific clues to developing new food resources.

\section{Acknowledgements}

This study was supported by the Ministry of Education of China through its 111 and 985 projects (B08044, MUC 98503001006 \& MUC 98502-006004), the National Natural Science Foundation of China (31070288 \& 31161140345), and the Ministry of Science and Technology of China (2012FY110300).

\section{References}

1. Hu SY. Food plants of China. Hong Kong: Chinese University Press; 2005.

2. Pei SJ. Preliminary ethnobotanical study of Xishuangbanna. In: Proceedings of tropical plants researches. Kunming: Yunnan People’s Press; 1982. p. 16-32.

3. Dao ZL, Long CL, Liu YT. On traditional uses of plants by the Nu people community of the Gaoligong Mountains, Yunnan Province. Sheng Wu Duo Yang Xing. 2003;11(3):231-239.

4. Li QJ, Liu HM, Xu YK, Chen J, Xu ZF. Changes in species number and causes that used as wild vegetableby Dai people in Xishuangbanna, China. Acta Bot Yunnan. 2007;29(4):467-478.

5. Khasbagan, Soyolt, Man L, Enhebayar, Gerelt, Hu W. Traditional usage of wild plants for food by the Ejina Mongolians and its exploitation and ethnoecological significance. Journal of Inner Mongolia Normal University (Natural Science Edition). 2005;34(4):471-488.

6. Liu YT, Long CL, Dao ZL. Ethnobotanical survey on medicinal roots eaten by the local people in Simao, Yunnan Province, during the Dragon-boat Festival. Journal of Plant Resources and Environment. 2003;12(2):33-38.

7. Wang JR, Long CL. Ethnobotanical study of traditional edible plants of Jinuo nationality. Acta Bot Yunnan. 1995;17(2):161-168.

8. Long CL, Li H, Zhou YL, Dao ZL, Abe T. Ethnobotanical studies in Gaoligong Mountains: II. the Dulong ethnic group. Acta Bot Yunnan. 1999;11 suppl:137-144.

9. Long CL, Li H, Dao ZL, Zhou YL. Ethnobotanical studies in Gaoligong Mountains: I. the Dulong ethnic group. Acta Bot Yunnan. 1999;11 suppl:131-136.

10. Jin S, Tie J, Liu RX. Ethnobotanical study on folk wild edible plants in southeast region of Shanxi province. Journal of Jindongnan Normal College. 2004;21(2):13-15.

11. Khasbagen, Huai HY, Pei SJ. Wild plants in the diet of arhorchin mongol herdsmen in inner mongolia. Econ Bot. 2000;54(4):528-536. http://dx.doi. org/10.1007/BF02866550

12. Wujisguleng W, Khasbagen K. An integrated assessment of wild vegetable resources in Inner Mongolian Autonomous Region, China. J Ethnobiol Ethnomed. 2010;6(1):34. http://dx.doi.org/10.1186/1746-4269-6-34
13. World checklist of selected plant families [Internet]. Kew Royal Botanic Gardens. 2012 [cited 2012 Jul 7]; Available from: http://apps.kew.org/ wcsp/prepareChecklist.do;jsessionid=EE82AA0DBD9A249F1939FB9 DE7E211B4?checklist=selected_families $\% 40 \% 40298241020120745409$

14. Haroon K, Muhammad S, Naveed M. Pharmacological and phytochemical updates of genus Polygonatum. Phytopharmacology. 2012;3(2):286-308.

15. Li JH, Zhou SB. Utilization of Polygonatum resources and its assessment of economic value. Anhui Agricultural Science Bulletin. 2006;12(5):64-65.

16. Yang CR, Zhang Y, Wang D, Zhang YJ. Molecular evolution of steroidal saponins in the genus Polygonatum (Convalleriaceae) and their chemotaxonomical significance. Acta Bot Yunnan. 2007;29(5):591-600.

17. Polygonatum [Internet]. eFloras.org. 2012 [cited 2012 Aug 25]; Available from: http://www.efloras.org/florataxon. aspx?flora_id=2\&taxon_id=126394

18. Youn YN, Lim E, Lee N, Kim YS, Koo MS, Choi SY. Screening of Korean medicinal plants for possible osteoclastogenesis effects in vitro. Genes Nutr. 2007;2(4):375-380. http://dx.doi.org/10.1007/s12263-007-0062-1

19. Misra S, Maikhuri RK, Kala CP, Rao KS, Saxena KG. Wild leafy vegetables: a study of their subsistence dietetic support to the inhabitants of Nanda Devi Biosphere Reserve, India. J Ethnobiol Ethnomed. 2008;4(1):15. http://dx.doi.org/10.1186/1746-4269-4-15

20. Polygonatum biflorum [Internet]. Missouri Botanical Garden. 2012 [cited 2012 Aug 25]; Available from: http://www.missouribotanicalgarden. org/gardens-gardening/your-garden/plant-finder/plant-details/kc/e750/ Polygonatum-biflorum.aspx

21. Huang JS, Peng YL, Li M, Wang Y. Exploitation and utilization of wild vegetables in the north of Hunan. Chinese Wild Plants Resources. 2002;21(6):39-40.

22. Su SL, Ma B, Huang K. Research on the ethnobotany of Panax notoginseng. Anhui Agricultural Science Bulletin. 2012;18(1):56-58.

23. Zhou Y. The Polygonatum plant resources in Changbai Mountains and their exploitation. Chinese Wild Plants Resources. 2002;21(2):34-35.

24. Wang ZK, Wang ZH, Xing Z, Li RQ, Liu H, Deqingcuomu. Preliminary investigation and studies on wild vegetable resources in Nyingtri, Tibet. China Vegetables. 2010;2:75-78.

25. Feng BC, Yu MS, Xu GF, Yan SF, Chen AM, Liu WH, et al. Exploiting and utilizing edible wild plants in Thousand-Isle Lake. Central South Forest Inventory and Planning. 2010;29(1):41-44.

26. Xu LZ. Exploitation and utilization of the wild vegetable resource in northeastern Guangdong province. Anhui Agricultural Science Bulletin. 2006;3(12):2690-2694.

27. Zhu Q, Guo S, Wang J, Tian Y. Investigation on the wild edible plant resources in Ningxia. Journal of Ningxia University (Natural Science Edition). 2004;28(4):367-371.

28. Khasbagen, Soyolt, editors. Wild vegetable resources in Inner Mongolia and their ethnobotanical study. Beijing: Science Press; 2008.

29. Han YX, Zhao CH, Jing ZP, Li GF, Gong FL, Chen SY, et al. Hill wild vegetables investigation in Huzhubeishan forest region. Qinghai Prataculture. 2001;10(2):46-49.

30. Fan SJ, Zhao ZT. Wild vegetable blog in Shandong. Jinan: Shandong Science and Technology Press; 1996.

31. Dong R, Li GC, Fan SL. Wild vegetables in Changbai Mountains. Beijing: Science Press; 1997.

32. Zhao JG, Wei XB, Guo WC. Chinese potherb. Changchun: Jilin Science and Technology Press; 2004.

33. Dong SY, Wei CR, Yang CJ. Recipes of Chinese wild vegetables. Beijing: China Tourism Press; 1993.

34. Khasbagan, Pei SJ. Wild plants used for the folk dietotherapy in Arhorchin Mongolians. Zhong Yao Cai. 2001;24(2):83-85.

35. Bureau of Production \& Consumption of Chinese Ministry of Commerce, Institute of Botany of Chinese Academy of Sciences. Flora of Chinese economic plants. Beijing: Science Press; 2012. (Flora of Chinese economic plants; vol 1). 
36. Wang ZX. China resources plants utilization manual. Beijing: Chinese Science and Technology Press; 1989.

37. China Pharmacopoeia Committee. China Pharmacopoeia. Beijing: Chinese Medicine and Technology Press; 2010. (China Pharmacopoeia; vol 1).

38. Liu L. Purification, structure identification, biological activity and structure-activity relationship research of polygona polysaccharides. Shanghai: Shanghai Institute of Materia Medica; 2005.

39. Zhang TT, Xia XK, Chen CP, Wu AP, He M, Nie LW. Biological activities of polysaccharides from Polygonatum sibiricum Redoute. Chinese Journal of Experimental Traditional Medical Formulae. 2006;12(7):42-45.

40. Hu CY, Xu DP, Wu YM, Ou SY. Triterpenoid saponins from the rhizome of Polygonatum sibiricum. J Asian Nat Prod Res. 2010;12(9):801-808. http:// dx.doi.org/10.1080/10286020.2010.505562

41. Deng Y, He K, Ye X, Chen X, Huang J, Li X, et al. Saponin rich fractions from Polygonatum odoratum (Mill.) Druce with more potential hypoglycemic effects. J Ethnopharmacol. 2012;141(1):228-233. http://dx.doi. org/10.1016/j.jep.2012.02.023

42. Janeczko Z, Jansson P, Sendra J. A new stereoidal saponin from Polygonatum officinale. Planta Med. 2007;53(1):52-54. http://dx.doi. org/10.1055/s-2006-962618

43. Yu HS, Ma BP, Kang LP, Zhang T, Jiang FJ, Zhang J, et al. Saponins from the processed rhizomes of Polygonatum kingianum. Chem Pharm Bull. 2009;57(9):1011-1014.

44. Hirai N, Miura T, Moriyasu M, Ichimaru M, Nishiyama Y, Ogura K, et al. Cardiotonic activity of the rhizome of Polygonatum sibiricum in rats. Biol Pharm Bull. 1997;20(12):1271-1273.

45. Lin HW, Han GY, Liao SX. Studies on the active constituents of the Chinese traditional medicine Polygonatum odoratum (Mill.) Druce. Yao Xue Xue Bao. 1994;29(3):215-222.

46. Khan H, Saeed M, Gilani AU, Khan MA, Dar A, Khan I. The antinociceptive activity of Polygonatum verticillatum rhizomes in pain models. J Ethnopharmacol. 2010;127(2):521-527. http://dx.doi.org/10.1016/j. jep.2009.10.003
47. Li XC, Yang CR, Makoto I, Hiromichi M, Ryoji K, Kazuo Y. Steroid saponins from Polygonatum kingianum. Phytochemistry. 1992;31(10):35593563. http://dx.doi.org/10.1016/0031-9422(92)83727-G

48. Liu B, Cheng Y, Bian HJ, Bao JK. Molecular mechanisms of Polygonatum cyrtonema lectin-induced apoptosis and autophagy in cancer cells. Autophagy. 2009;5(2):253-255.

49. Liu F, Liu Y, Meng Y, Yang M, He K. Structure of polysaccharide from Polygonatum cyrtonema Hua and the antiherpetic activity of its hydrolyzed fragments. Antiviral Res. 2004;63(3):183-189. http://dx.doi.org/10.1016/j. antiviral.2004.04.006

50. Ye HC, Zhang XP, Gao GB, Jiang JH. Chemical constituents and biological activity of volatile oil from the tubers of Polygonatum filipes. Guihaia. 2009;29(3):417-419.

51. Materia medica for dietotherapy [Internet]. 2012 [cited 2012 Aug 25]; Available from: http://baike.baidu.com/view/1080230.htm

52. Polygonatum spp. [Internet]. Poisonous plants. 2012 [cited 2012 Aug 25]; Available from: http://www.ces.ncsu.edu/depts/hort/consumer/poison/ Polygsp.htm

53. Li YG, Ji JY, Zhang YJ. Measurement and analysis of the nutrients of Polygonatum sibiricum seeds. Xibei Zhiwu Xuebao. 2009;29(8):1692-1696.

54. Li JH, Zhou SB. Advances in Polygonatum from Anhui Province. Chinese Wild Plant Resources. 2005;24(5):17-19.

55. Sun Z. An investigation of three species of Polygonatum and quality assessment of Polygonatum cirrhifolium (Wall.) Royle. Beijing: Beijing University of Chinese Medicine; 2009.

56. Balemie K, Kebebew F. Ethnobotanical study of wild edible plants in Derashe and Kucha Districts, South Ethiopia. J Ethnobiol Ethnomed. 2006;2:53. http://dx.doi.org/10.1186/1746-4269-2-53

57. Kang Y, Łuczaj Ł, Zhang S, Kang J. Wild food plants and wild edible fungi of Heihe valley (Qinling Mountains, Shaanxi, central China): herbophilia and indifference to fruits and mushrooms. Acta Soc Bot Pol. 2012;81(4):405-413. http://dx.doi.org/10.5586/asbp.2012.044 